\title{
Pengaruh Ideologi Peran Jender terhadap Pemberian Dukungan kepada Calon Pemimpin Perempuan pada Organisasi Kemahasiswaan
}

\author{
Rochimah Imawati ${ }^{1 *}$ dan Radhiya Bustan ${ }^{1,2}$ \\ ${ }^{1}$ Program Studi Psikologi, Fakultas Psikologi dan Pendidikan, \\ Universitas Al Azhar Indonesia, Jl. Sisingamangaraja, Jakarta 12110 \\ ${ }^{2}$ Program Studi Healing dan Konseling, Fakultas Psikologi dan Pendidikan, \\ Universitas Al Azhar Indonesia, Jl. Sisingamangaraja, Jakarta 12110 \\ *Penulis untuk Korespondensi: rochimah@uai.ac.id
}

\begin{abstract}
Abstrak - Jender sering dipahami sebagai karakter yang melekat dalam diri perempuan maupun lak-laki yang dikonstruksi secara sosial maupun kultural. Konstruksi tersebut secara langsung atau tidak menimbulkan harapan yang berbeda terhadap ideal selves laki-laki dan perempuan. Penelitian ini berusaha untuk melihat bagaimana ideologi peran jender dalam pemilihan pemimpin perempuan pada organisasi kemahasiswaan (intra kampus) di UAI tahun 2009.
\end{abstract}

Abstrack - Gender was often understood as a character inherent inboth women and men, who socially and culturally constructed. This construction was directly or indirectly leads to different expectations of the ideal selves of male and female. This study attempted to discuss how ideology of gender roles in the election of women leaders in student organizations (intra-campus) at UAI, 2009.

Keywords - ideology of gender, leadership, college student organizational

\section{PENDAHULUAN}

\subsection{Latar Belakang}

$\mathrm{D}$ ewasa ini masyarakat Indonesia masih menganut budaya patrikiakis. Yakni masyarakat memberikan sosialisasi dan penghargaan yang berbeda. Anak laki-laki diperlakukan secara berbeda dan didorong untuk terlibat dalam jenis kegiatan tertentu sedangkan anak perempuan didorong untuk berpartisipasi dalam kegiatan yang berbeda dengn anak laki-laki. Keterlibatan dalam kegiatan-kegiatan itu dan asosiasi terhadap reward memberikan alasan lain bagi perempuan untuk mempersepsikan dirinya berbeda dengan laki-laki dan hal ini menimbulkan harapan yang berbeda terhadap ideal selves lakilaki dan perempuan. Kenyataan ini mengakibatkan pemahaman konsep jender menjadi bias dan terdistorsi, sehingga menimbulkan kesimpangsiuran dan kerancauan dalam perlakuan antara perempuan dan laki-laki.

Jender sering dipahami sebagai karakter yang melekat pada perempuan maupun lak-laki yang terkonstruksi secara sosial maupun kultural. Konstruksi tersebut cenderung lebih menguntungkan laki-laki daripada perempuan. Misalnya laki-laki dianggap kuat, rasional, jantan perkasa dan lain-lain; sementara perempuan dikenal lemah lembut, cantik, keibuan, emosional, penakut, dan sebagainya.

Sebetulnya karakteristik yang dimiliki, baik lakilaki maupun perempuan dapat dipertukarkan (interchangeable). Artinya sifat-sifat yang dimiliki oleh laki-laki pasti dimiliki juga oleh perempuan demikian juga sebaliknya.

Karena itu diperlukan rekonstruksi pemahaman yang lebih integral dan komprehensif, sehingga tidak bias, tetapi lebih menguntungkan kedua belah pihak, baik laki-laki maupun perempuan. 
Selanjutnya, pengertian organisasi secara sederhana adalah kesatuan dari beberapa orang yang membentuk komunitas dengan usaha sadar bersama-sama mencapai suatu tujuan tertentu. Manusia sebagai makhluk sosial membutuhkan jasa orang lain, saling membutuhkan dalam proses pemberdayaan dan perjuangan ditengah-tengah kehidupan masyarakat. Kecenderungan berinteraksi selalu timbul hingga mewujudkan suatu komunitas dengan beberapa impian/keinginan untuk diperjuangkan.

Dilingkungan kampus, organisasi merupakan wadah dari berbagai macam aktivitas mahasiswa, dimana (1) organisasi menawarkan pengalaman berharga yang hal tersebut tidak akan diperoleh hanya diperkuliahan, (2) organisasi memberikan kerangka praktis dari teori-teori yang telah didapatkan dikuliah, dan (3) organisasi mampu memupuk kepedulian mahasiswa terhadap sesamanya dan dilingkungan sekitarnya baik dari aspek sosial, ekonomi, budaya, hukum dan lainlain. Selain dinyatakan sebagai wadah yang mampu merespon apa kepentingan suatu kelompok tertentu, organisasi juga sebagai proses yang ideal bagaimana kemudian mahasiswa mampu mengaktualisasikan dirinya sebagai agen perubahan sosial.

Saat Pemilu Mahasiswa untuk memilih Pemimpin Organisasi Mahasiswa, pertarungan terjadi diantara para kandidat baik aktivis intra kampus itu sendiri maupun antar aktivis yang berasal dari organisasi ekstra kampus ataupun aktivis-aktivis independen lain yang berasal dari berbagai kelompok studi atau kelompok kegiatan lainnya.

Partisipasi kandidat perempuan dalam pemilihan kepemimpinan organisasi kampus memang bukan hal baru. Terpilihnya seorang kandidat perempuan dalam pemilihan kepemimpinan organisasi kampus dipengaruhi oleh beberapa hal yang berkisar antara lain pada kompetensi, orientasi program dan kemampuan meyakinkan calon pemilihnya. Akan tetapi faktor penting yang turut mempengaruhi terpilih tidaknya seorang kandidat perempuan dalam pemilihan pemimpin organisasi mahasiswa dalam hal ini organisasi intra kampus adalah ideologi dari para pemilih itu sendiri terutama pemilih perempuan, apakah ia akan lebih percayakan pilihannya kepada kandidat perempuan untuk menjadi pemimpin berdasarkan pemahaman konsep jender yang dimilikinya.

\subsection{Tujuan Penelitian}

Penelitian ini bertujuan untuk mengungkapkan:

1) Bagaimana ideologi peran jender mahasiswa Universitas Al Azhar Indonesia.

2) Melihat apakah ideologi peran jender memberikan pengaruh terhadap pemberian dukungan kepada calon pemimpin perempuan pada organisasi kemahasiswaan.

3) Melihat apakah terdapat perbedaan ideologi peran jender antara pemilih yang memilih calon pemimpin perempuan dengan yang memilih calon pemimpin laki-laki.

\subsection{Manfaat Penelitian}

Penelitian ini diharapkan dapat memberikan manfaat, secara akademis dan secara praktis.

1) Secara akademis,

Penelitian ini diharapkan dapat memberikan manfaat dan memperkaya literatur bidang kajian sosial (misal. studi psikologi, studi ilmu sosial, studi politik, studi budaya maupun studi keagamaan) dan keterkaitannya dengan isu jender.

2) Secara praktis,

Penelitian ini dapat dimanfaatkan untuk mengembangkan strategi dalam meningkatkan partisipasi mahasiswa sebagai generasi muda bangsa dalam kegiatan politik -pemilihan pemimpin- pada umumnya.

\section{KERANGKA TEORI / TINJAUAN PUSTAKA}

\subsection{Ideologi Peran Jender}

Ideologi peran jender (sex role ideology) adalah bagian dari studi mengenai jender. Jender mengacu pada makna yang terkait dengan laki-laki dan perempuan, yang direfleksikan pada status sosial, peran, dan sikap menurut jenis kelaminnya (Segall, 1999). Ada tiga isu yang terkait dengan jender, yaitu peran jender (gender role), identitas gender (gender identity), dan ideologi peran jender.

Peran jender adalah ketentuan mengenai tingkah laku laki-laki dan perempuan secara budaya misalnya pembagian pekerjaan berdasarkan jenis kelamin. Sedangkan identitas jender adalah bagaimana seorang menerima dirinya berdasarkan jenis kelamin dan peran jender. Ketiga konsep ini saling berhubungan, misalnya bagaimana seseorang 
mendefinisikan peran jendernya merupakan pengaruh dari ideologi peran jendernya (Segall, 1999).

Ideologi peran jender adalah kepercayaan individu mengenai peran hubungan yang tepat antara perempuan dan laki-laki (William \& Best,1990). Tiap masyarakat mengembangkan ketentuanketentuan mengenai tata cara laki-laki dan perempuan berhubungan satu dengan yang lain. Sistem kepercayaan ini terkadang eksplisit dan spesifik, terkadang implisit dan umum. Ketentuan ini adalah segi penting pada semua kelompok masyarakat dan individu yang memilih melanggar norma ini, akan mengalami penolakan dari masyarakat dan bisa jadi berupa sanksi.

Ada berbagai cara untuk mengklasifikasikan ideologi peran jender, tergantung budaya yang berlaku. Penelitian ini menggunakan klasifikasi yang memiliki kontinum dari tradisional sampai modern. Ideologi tradisional menganggap laki-laki lebih penting daripada perempuan dan karena itu sangat tepat bagi laki-laki untuk memegang kontrol dan dominasi terhadap perempuan. Ideologi modern menampilkan sudut pandang yang lebih egaliter dan menolak gagasan bahwa salah satu harus menguasai yang lain (William dan Best, 1990).

Middlebrook (1980) menyatakan bahwa terdapat perbedaan individual dalam hal pandangan mengenai peran jender. Individu yang memiliki pandangan peran jender tradisional menekankan pada perbedaan antara laki-laki dan perempuan (Hurlock, 1991). Laki-laki dipandang sebagai superior daripada perempuan. Sedangkan perempuan diharapkan untuk mendapatkan kepuasan lewat pengabdian pada orang lain (Middlebrook, 1980).

Ideologi tradisional menganggap peran perempuan yang paling penting adalah sebagai ibu rumah tangga yang mengatur rumah dan merawat anak, sedangkan laki-laki diposisikan sebagai kepala rumah tangga yang mencari nafkah. Pandangan ini berpendapat perempuan harus mendukung karier suami dan menolongnya dengan segala cara tidak hanya dalam pekerjaan tetapi juga pada prestasiprestasi yang lain. Perempuan dinilai atas keberhasilan suami dan perempuan yang lebih sukses daripada pasangannya dianggap memalukan. Laki-laki dengan ideologi tradisional merasa terancam dengan perempuan yang sukses dan mengumpulkan uang lebih banyak. Perempuan tidak didorong untuk berkarier dan memiliki prestasi di luar rumah terutama pada bidang-bidang yang secara tradisional dianggap bidang-bidang laki-laki seperti politik, militer, teknik.

Pandangan mengenai peran jender yang modern didasari oleh prinsip bahwa laki-laki dan perempuan adalah sama. Pandangan ini menganggap bahwa baik laki-laki dan perempuan memiliki peran yang sama dalam masyarakat. Mereka tidak menolak adanya peran jender namun tidak memandang peran jender secara kaku. Perempuan diberi kebebasan untuk berkarier dan meraih prestasi di luar rumah. Pembagian tugas rumah tangga menjadi lebih seimbang antara suami dan istri. Laki-laki semakin terlibat dalam perawatan dan pendidikan anak.

Beberapa instrumen telah dikembangkan untuk mengukur ideologi peran jender, antara lain, skala Attitudes Toward Women (ATW) dikembangkan oleh Spence dan Helmreich $(1972,1973)$ dan skala Sex Role Ideology (SRI) dikembangkan oleh Kalin dan Tilby (1978). Penelitian ini menggunakan instrument skala Sex Role Ideology (SRI) untuk mengukur ideologi peran jender dari tradisional sampai modern. Penelitian mengenai ideologi peran jender pada 14 negara menggunakan skala SRI (Williams dan Best, 1990) menunjukkan perempuan memiliki ideologi peran jender yang lebih liberal daripada laki-laki. Perempuan memiliki pandangan yang lebih egaliter pada hubungan peran jender dibandingkan dengan lakilaki yang ternyata lebih tradisional. Ideologi peran jender akan semakin modern pada negara yang memiliki tingkat pertumbuhan sosial ekonomi yang tinggi. Ideologi peran jender yang semakin modern berkorelasi positif dengan semakin banyaknya jumlah perempuan yang bekerja di luar rumah dan mengenyam pendidikan di universitas.

Pandangan tradisional pemilih -dalam hal ini pemilih perempuan- mengenai peran perempuan akan mempengaruhi terpilih tidaknya seorang kandidat perempuan dalam suatu pemilihan. Pemilih dengan ideologi tradisional memandang laki-laki lebih asertif, independen, dan memiliki kemampuan untuk menjadi seorang pemimpin. Sebaliknya perempuan dilihat lebih penyayang, memahami perasaan dan kebutuhan orang lain, dan dianggap kurang mampu menjadi pemimpin, mereka hanya sebagai pengikut (follower) dari apa yang sudah diputuskan oleh pemimpin. Individu yang memiliki pandangan tradisional akan lebih memiliki kecenderungan untuk tidak memilih calon 
pemimpin perempuan karena mereka menganggap perempuan tidak memiliki kemampuan untuk menjadi pemimpin, dalam hal ini sebagai pemimpin organisasi mahasiswa intra kampus.

Sedangkan pemilih yang berideologi modern menganggap laki-laki dan perempuan memiliki kapasitas yang setara untuk melakukan berbagai aktivitas, dan akan lebih mau untuk memilih kandidat perempuan. Penelitian yang dilakukan Lopez (2002) pada pemilih di Amerika Serikat menunjukkan pemilih yang memiliki ideologi modern akan lebih mau untuk memilih kandidat perempuan, dibandingkan pemilih dengan ideologi tradisional.

\subsection{Pemimpin Organisasi Mahasiswa Intra Kampus}

\subsubsection{Organisasi Mahasiswa}

Organisasi Mahasiswa adalah organisasi yang beranggotakan mahasiswa. Organisasi ini dapat berupa organisasi kemahasiswaan intra kampus, organisasi kemahasiswaan ekstra kampus, maupun semacam ikatan mahasiswa kedaerahan yang pada umumnya beranggotakan lintas-kampus. Sebagian organisasi mahasiswa di kampus Indonesia juga membentuk organisasi mahasiswa tingkat nasional sebagai wadah kerja sama dan mengembangkan potensi serta partisipasi aktif terhadap kemajuan Indonesia. Sementara di luar negeri juga terdapat organisasi mahasiswa berupa Perhimpunan Pelajar Indonesia, yang beranggotakan pelajar dan mahasiswa Indonesia.

Organisasi kemahasiswaan intra kampus adalah organisasi mahasiswa yang memiliki kedudukan resmi di lingkungan kampus dan mendapat pendanaan kegiatan kemahasiswaan dari kampus. Penelitian ini mengacu pada organisasi kemahasiswaan intra kampus.

Para aktivis Organisasi Mahasiswa Intra Kampus pada umumnya juga berasal dari kader-kader organisasi ekstra kampus ataupun aktivis-aktivis independen yang berasal dari berbagai kelompok studi atau kelompok kegiatan lainnya. Saat Pemilu Mahasiswa untuk memilih Pemimpin Senat Mahasiswa, pertarungan antar organisasi ekstra kampus cukup terasa.

Dalam lintasan sejarah dan proses pembentukan organisasi mahasiswa dapat diperincikan sebagai berikut: Dewan Mahasiswa dan Majelis Mahasiswa. Dewan Mahasiswa dan Majelis
Mahasiswa adalah Lembaga intra kemahasiswaan tingkat Universitas. Dewan Mahasiswa ini sangat independen, dan merupakan kekuatan yang cukup diperhitungkan sejak Indonesia merdeka hingga masa Orde Baru berkuasa. Ketua Dewan Mahasiswa selalu menjadi kader pemimpin nasional yang diperhitungkan pada jamannya. Dewan Mahasiswa berfungsi sebagai lembaga eksekutif sedangkan Majelis Mahasiswa adalah menjalankan fungsi legislatifnya. Pada tiap fakultas dibentuklah Komisariat Dewan Mahasiswa biasa disebut KODEMA, dibeberapa perguruan tinggi disebut Senat Mahasiswa. Para Ketua Umum KODEMA atau Ketua Umum Senat Mahasiswa ini secara otomatis mewakili fakultas di Majelis Mahasiswa. Keduanya dipilih secara langsung dalam Pemilu Badan Keluarga Mahasiswa untuk masa jabatan dua tahun. Sedang Ketua Umum Dewan Mahasiswa dipilih dalam sidang umum Majelis Mahasiswa.

\subsubsection{Senat Mahasiswa}

Senat mahasiswa adalah organisasi mahasiswa intra universitas yang dibentuk pada saat pemberlakuan kebijakan NKK/BKK pada tahun [1978]. Sejak 1978-1989, Senat Mahasiswa hanya ada di tingkat fakultas, sedangkan tingkat universitas ditiadakan. Di tingkat jurusan keilmuan dibentuk Keluarga Mahasiswa Jurusan atau Himpunan Mahasiswa Jurusan, yang berkoordinasi dengan Senat Mahasiswa dalam melakukan kegiatan intern. Pada umumnya Senat Mahasiswa dimaksudkan sebagai Lembaga Eksekutif, sedangkan fungsi legislatifnya dijalankan organ lain bernama Badan Perwakilan Mahasiswa (BPM).

Pada tahun 1990, pemerintah memperbolehkan dibentuknya Senat Mahasiswa tingkat Perguruan Tinggi namun model student government ala Dewan Mahasiswa tidak diperbolehkan. Senat Mahasiswa yang dimaksudkan adalah kumpulan para Ketua-Ketua Lembaga Kemahasiswaan yang ada: Ketua Umum Senat Mahasiswa Fakultas, Ketua Umum BPM dan Ketua Umum Unit Kegiatan Mahasiswa.

Senat Mahasiswa menjelma menjadi Lembaga Legislatif, termasuk di tingkat Fakultas. Lembaga Eksekutifnya adalah Badan Pelaksana Senat Mahasiswa. Belakangan nama Badan Pelaksana diganti dengan istilah yang lebih praktis : Badan Eksekutif Mahasiswa (BEM). Awalnya BEM dipilih, dibentuk dan bertanggung jawab kepada Sidang Umum Senat Mahasiswa namun sekarang 
pengurus kedua institusi sama-sama dipilih langsung dalam suatu Pemilihan Umum.

\subsubsection{Badan Eksekutif Mahasiswa}

Badan Eksekutif Mahasiswa (BEM) ialah lembaga kemahasiswaan yg menjalankan organisasi serupa pemerintahan (lembaga eksekutif). Dipimpin oleh Ketua/Presiden BEM yang dipilih melalui pemilu mahasiswa setiap tahunnya. Di beberapa kampus seperti Universitas Indonesia, masih digunakan nama Senat Mahasiswa (SM).

\subsubsection{Himpunan Mahasiswa Jurusan}

Himpunan Mahasiswa Jurusan adalah organisasi mahasiswa intra kampus yang terdapat pada jurusan keilmuan dalam lingkup fakultas tertentu. Umumnya bersifat otonom dalam kaitannya dengan organisasi mahasiswa di tingkat Fakultas seperti Senat Mahasiswa dan Badan Eksekutif Mahasiswa. Kegiatan Himpunan Mahasiswa Jurusan umumnya dalam konteks keilmuan, penalaran dan pengembangan profesionalisme. Nama lain Himpunan Mahasiswa Jurusan adalah Keluarga Mahasiswa Jurusan atau Keluarga Mahasiswa Fakultas (KMF) yang sesuai dengan penelitian ini.

\subsubsection{Kepemimpinan}

Salah satu prestasi yang cukup menonjol dari Sosiologi tentang kepemimpinan modern adalah perkembangan dari teori peran (role theory). Dikemukakan, setiap anggota suatu masyarakat menempati status posisi tertentu, demikian juga halnya dengan individu diharapkan memainkan peran tertentu. Dengan demikian kepemimpinan dapat dipandang sebagai suatu aspek dalam diferensiasi peran. Ini berarti bahwa kepemimpinan dapat dikonsepsikan sebagai suatu interaksi antara individu dengan anggota kelompoknya.

Menurut kaidah, para pemimpin atau manajer adalah manusia-manusia super lebih daripada yang lain, kuat, gigih, dan tahu segala sesuatu. Para pemimpin juga merupakan manusia-manusia yang jumlahnya sedikit, namun perannya dalam organisasi sbg penentu keberhasilan dan suksesnya tujuan yang hendak dicapai. Berangkat dari ide-ide pemikiran, visi para pemimpin ditentukan arah perjalanan suatu organisasi. Walaupun bukan satusatunya ukuran keberhasilan dari tingkat kinerja organisasi, akan tetapi kenyataan membuktikan tanpa kehadiran pemimpin, suatu organisasi akan bersifat statis dan cenderung berjalan tanpa arah.

Dengan demikian, dalam suatu organisasi, kepemimpinan merupakan faktor yang sangat penting dalam menentukan pencapaian tujuan yang telah ditetapkan oleh organisasi. Kepemimpinan merupakan titik sentral dan penentu kebijakan dari kegiatan yang akan dilaksanakan organisasi. Kepemimpinan adalah aktivitas untuk mempengaruhi perilaku orang lain agar supaya mereka mau diarahkan untuk mencapai tujuan tertentu. Sedangkan menurut Robbins, kepemimpinan adalah kemampuan untuk mempengaruhi suatu kelompok untuk mencapai tujuan. Artinya, kepemimpinan adalah sekumpulan dari serangkaian kemampuan dan sifat-sifat kepribadian, termasuk didalamnya kewibawaan, untuk dijadikan sebagai sarana dalam rangka meyakinkan yang dipimpinnya agar mereka mau dan dapat melaksanakan tugas-tugas yang dibebankan kepadanya dengan rela, penuh semangat, ada kegembiraan batin, serta merasa tidak terpaksa. Dari pengertian diatas kepemimpinan mengandung beberapa unsur pokok antara lain: 1) kepemimpinan melibatkan orang lain dan adanya situasi kelompok atau organisasi tempat pemimpin dan anggotanya berinteraksi, 2) di dalam kepemimpinan terjadi pembagian kekuasaan dan proses mempengaruhi bawahan oleh pemimpin, dan 3) adanya tujuan bersama yang harus dicapai. Dari uraian diatas dapat diambil kesimpulan bahwa kepemimpinan adalah kemampuan untuk mempengaruhi perilaku seseorang atau sekelompok orang untuk mencapai tujuan tertentu pada situasi tertentu.

\subsection{Kerangka Konseptual}

Mahasiswa sebagai salah satu elemen sosial kampus memposisikan dirinya sebagai organ civitas akademika, yang diasumsikan bahwa sebagai masyarakat kampus mahasiswa dianggap lebih berpotensi intelektual dalam perilaku ilmiah, obyektif dan bertanggungjawab. Entitas yang demikian mengharuskan mahasiswa mampu mengaktualisasikan citra diri insan akademik yaitu Tri Dharma Perguruan Tinggi dalam merealisasikan tanggungjawab kepada masyarakat akademik yang mampu mempertemukan antara teori dan aplikasi, diantaranya melalui organisasi kemahasiswaan intra kampus. Dimana antara mahasiswa dan mahasiswi memiliki peran dan kesempatan yang sama untuk menjadi pemimpin.

Dalam hubungannya dengan kesempatan untuk terpilihnya kandidat perempuan untuk menjadi pemimpin organisasi mahasiswa intra kampus, maka diduga ideologi konsep jender akan turut 
mempengaruhi terpilih atau tidak seorang kandidat perempuan dalam pemilihan yang terbuka.

\section{METODE PENELITIAN}

\subsection{Masalah, Hipotesis, dan Variabel Penelitian}

\subsubsection{Masalah Penelitian}

Berdasarkan uraian yang telah dilakukan, dapat dirumuskan masalah penelitian sebagai berikut:

1) Apakah ideologi peran jender berpengaruh terhadap pemberian dukungan kepada calon pemimpin perempuan pada organisasi kemahasiswaan?

2) Apakah ada perbedaan ideologi peran jender pemilih perempuan yang memilih calon pemimpim perempuan dan calon pemimpin laki-laki?

\subsubsection{Hipotesis}

Dalam penelitian ini dimunculkan hipotesis yang nantinya akan dibuktikan melalui penelitian berdasarkan apa yang telah dirumuskan sebelumnya dalam masalah penelitian;

Hipotesis alternatif (Ha) sebagai berikut:

1) Ada pengaruh ideologi peran jender terhadap pemberian dukungan kepada calon pemimpin perempuan pada organisasi kemahasiswaan.

2) Ada perbedaan ideologi peran jender pemilih perempuan yang memilih calon pemimpin perempuan dan calon pemimpin laki-laki.

Hipotesis null (Ho) sebagai berikut:

1) Tidak ada pengaruh ideologi peran jender terhadap pemberian dukungan kepada calon pemimpin perempuan pada organisasi kemahasiswaan.

2) Tidak ada perbedaan ideologi peran jender pemilih perempuan yang memilih calon pemimpim perempuan dan calon pemimpin laki-laki

\subsubsection{Variabel Penelitian}

Independen variable pada penelitian ini adalah "ideologi peran jender", dan dependen variabelnya adalah "pemberian dukungan kepada calon pemimpin perempuan".

\subsection{Subjek Penelitian}

\subsubsection{Karakteristik Subjek}

Subjek pada penelitian ini adalah pemilih perempuan dengan karakteristik sebagai berikut:
1) Mahasiswi universitas Al Azhar Indonesia semester 5 keatas.

2) Mempergunakan hak pilihnya pada pemilihan ketua KMF (Keluarga Mahasiswa Fakultas) pada periode kepemimpinan yang sedang berjalan saat ini.

3) Bersedia mengisi skala penelitian.

\subsubsection{Jumlah Subjek}

Jumlah subjek pada penelitian ini adalah 50 orang mahasiswi Universitas Al Azhar Indonesia semester 5 ke atas, karena disemester tersebut mahasiswi dianggap sudah memahami mengenai ideologi peran jender.

\subsubsection{Teknik Pengambilan Sampel}

Teknik pengambilan sampel yang digunakan dalam penelitian ini adalah purpossive sampling dengan cara incidental sampling, artinya individu yang telah memenuhi kriteria-kriteria yang ditentukan (purpossive sampling) dapat diambil sebagai subjek penelitian, dan diambil yang paling mudah ditemui atau yang secara tidak sengaja bertemu dengan peneliti dan bersedia menjadi sampel (incidental sampling), sampai jumlahnya mencapai batas yang diperlukan (Guilford \& Fruchter, 1981).

\subsection{Alat Penelitian}

Penelitian ini menggunakan alat penelitian berupa kuesioner. Kuesioner adalah alat pengumpul data yang berupa daftar pertanyaan atau pernyataan tertulis yang dijawab sesuai dengan keadaan subjek. Kuesioner dapat dijawab dengan berbagai cara, antara lain, melalui wawancara tatap muka, diisi sendiri oleh subjek, dijawab melalui telepon, atau pos. Pengisian kuesioner pada penelitian ini diisi sendiri oleh subjek.

Beberapa kelebihan kuesioner menurut Gorden (dalam Rosethal dan Rosnow, 1984) adalah sebagai berikut:

1) Nyaman digunakan karena dapat diadministrasikan kepada banyak orang dalam satu waktu.

2) Lebih ekonomis jika dibandingkan dengan wawancara mendalam.

3) Responden merasa lebih aman karena anonimitas pada kuesioner.

Kuesioner pada penelitian ini terdiri dari empat skala yang masing-masing mengukur satu variabel independen. Kerlinger dan Lee (2000) mendefinisikan skala sebagai satu item verbal dimana individu merespon setiap item dengan cara 
mengekspresikan derajat persetujuan, pertidaksetujuan, atau dengan cara respon lain.

Skala Sex Role Ideologi (SRI) yang dikembangkan oleh Kalin dan Tibly (dalam William dan Best, 1990) menunjukkan bahwa setiap subjek memperlihatkan derajat setuju atau tidak setuju dalam enam kontinum skala pada setiap pernyataan mengenai hubungan laki-laki dan perempuan. Skala SRI terdiri dari dua faktor penting. Pertama diinterpretasikan sebagai persetujuan terhadap keseluruhan tujuan dan nilai-nilai ideologi dari feminisme. Faktor kedua mengetengahkan persetujuan mengenai norma-norma dari keluarga tradisional yang berorientasi pada pembagian tugas yang dilandasi jender (Milo, Badger, dan Coggins dalam William dan Best, 1990).

Skala yang digunakan dalam penelitian ini adalah skala SRI yang sudah diadaptasi oleh Ilmi Amalia, M. Psi pada penelitiannya yang berjudul : "Peranan Faktor Jender, Isu Politik, dan Identifikasi Partai Politik pada Pemilihan Calon Legislatif Perempuan". Skala ini sudah melalui proses uji coba (pilot study), sehingga diperoleh item-item yang reliabel dengan koefisien Cronbach Alpha di atas 0,7 dan validitas yang terlihat dari nilai korelasi diatas 0,3. Item-item yang memiliki korelasi di bawah 0,3 dibuang atau diperbaiki. Tes yang item-itemnya dipilih berdasarkan metode ini dapat dikatakan telah menunjukkan konsistensi internal karena setiap item terdiferensiasi di antara responden pada arah yang sama dengan keseluruhan tes (Anastasi \& Urbina, 1997). Jumlah item pernyataan SRI yang disebar kepada responden sebanyak 22 item pernyataan, yang digolongkan menjadi lima aspek, yaitu:

1) peran perempuan dan laki-laki dalam bekerja: 6 item;

2) tanggung jawab perempuan dan laki-laki: 4 item;

3) hubungan personal antara laki-laki dan perempuan (berteman, berkencan, dan hubungan seksual): 4 item;

4) peran khusus perempuan dan konsep pedestal (pujaan): 4 item;

5) peran ibu, aborsi, dan homoseksualitas: 4 item.

Alat ini menggunakan metode skala Likert yang mempunyai 6 alternatif jawaban untuk setiap item, yaitu mulai dari sangat setuju sampai dengan sangat tidak setuju. Untuk pernyataan tradisional, sangat setuju mendapat skor 1, setuju mendapat skor 2, agak setuju mendapat skor 3, agak tidak setuju mendapat skor 4, tidak setuju mendapat skor 5, dan sangat tidak setuju mendapat skor 6. Untuk pernyataan modern skor dibalik sehingga sangat setuju mendapat skor 6 , setuju mendapat skor 5 , agak setuju mendapat skor 4, agak tidak setuju mendapat skor 3, tidak setuju mendapat skor 2, dan sangat tidak setuju mendapat skor 1 . Skor total didapat dengan menjumlahkan skor per item. Skor total dipandang sebagai keseluruhan indeks ideologi mengenai peran jender yang berkisar sepanjang dimensi tradisional sampai dengan dimensi modern.

\subsection{Teknik Pengolahan Data}

Pengolahan data dalam penelitian ini menggunakan analisis Dummy Regression untuk melihat pengaruh Independen Variabel terhadap Dependen Variabel.

Sedangkan untuk melihat perbedaan mean ideologi peran jender pemilih perempuan yang memilih calon pemimpim perempuan dan calon pemimpin laki-laki digunakan analisis statistik $T$-test dengan Independent Sample T Test.

\subsection{Profil Objek Penelitian}

\subsubsection{Profil Umum}

Universitas Al-Azhar Indonesia yang berdiri pada tahun 2000 dalam proses perjalanannya di tahun 2009 memiliki 6 fakultas dengan 2.882 mahasiswa. Dengan prosentasi $59 \%$ adalah mahasiswa perempuan dan $41 \%$ adalah mahasiswa laki-laki.

Organisasi intra kampus yaitu Badan Eksekutif Mahasiswa, atau biasa disingkat BEM. Terdiri atas: BEM tingkat Universitas, BEM tingkat Fakultas dan BEM tingkat Program Studi. Pada BEM tingkat Universitas belum pernah ada seorang perempuan yang menjabat sebagai pemimpin. Sedangkan pada tingkat fakultas atau program studi, yang biasa disebut dengan KMF (Keluarga Mahasiswa Fakultas) sudah pernah ada beberapa orang perempuan menjadi ketuanya.

Dengan demikian dapat dipastikan bahwa pemilih mahasiswa perempuan secara kuantitas lebih besar, dimana ideologi jender termasuk didalamnya sebagai variabel yang cukup berperan dalam pemilihan terhadap kandidat perempuan.

\subsubsection{Profil Responden}

Penelitian menggunakan kuesioner dalam bentuk skala ini disebar dibeberapa fakultas yang pernah memiliki seorang pemimpin perempuan, dimana objek penelitian adalah mahasiswa perempuan. 
Dengan perincian sebagai berikut, Program Studi Akutansi 24 orang, Ilmu Komunikasi13 orang, Gabungan HK, Paud, Psikologi 13 orang, Total 50 orang.

\section{HASIL DAN PEMBAHASAN}

\subsection{Deskripsi Hasil Penelitian}

Subjek penelitian adalah pemilih perempuan yaitu 50 orang mahasiswi Universitas Al Azhar Indonesia semester 5 ke atas dan sudah pernah mengikuti pemilihan ketua Keluarga Mahasiswa Fakultas (KMF) di fakultas masing-masing.

Ideologi peran jender diukur dengan menggunakan skala Sex Role Ideology (SRI) yang sudah diadaptasi. Skor total skala SRI dipandang sebagai keseluruhan indeks ideologi mengenai peran jender yang berkisar sepanjang dimensi tradisional sampai dengan dimensi modern dengan jumlah 22 item pernyataan. Skor tertinggi 6 dan terendah 1 untuk setiap item, maka kisaran skor dari dimensi ideologi tradisional sampai modern berkisar dari 22 sampai 132.

Hasil pengolahan data statistik untuk skoring ideologi peran jender (SRI) tersebut rata-rata nilainya 68,58 $(\mathrm{SD}=8,779)$, dengan skor maksimum 86 dan skor minimum 48. Deskriptif Statistik dan Frequensi skala SRI pada Tabel 1 dan Tabel 2.

Hasil pengolahan statistik juga menunjukkan bahwa pemilih yang memilih calon pemimpin perempuan pada organisasi kemahasiswaan berjumlah 33 orang dari 50 orang pemilih perempuan $(66 \%)$ dan pemilih yang memilih calon pemimpin laki-laki berjumlah 17 orang dari 50 orang pemilih perempuan ( $34 \%$ ). Terlihat pada Tabel 3.

Tabel 1. Descriptive Statistics

\begin{tabular}{lccc}
\hline & Mean & $\begin{array}{c}\text { Std. } \\
\text { Deviation }\end{array}$ & N \\
\hline Skor Skala SRI & 68,58 & 8,779 & 50 \\
$\begin{array}{l}\text { Dukungan kepada } \\
\text { Calon Pemimpin }\end{array}$ & 1,66 &, 479 & 50 \\
\hline
\end{tabular}

Tabel 2. Frequencies (Skor Skala SRI)

\begin{tabular}{cccc}
\hline & $\begin{array}{c}\text { Observed } \\
\text { N }\end{array}$ & $\begin{array}{c}\text { Expected } \\
\text { N }\end{array}$ & Residual \\
\hline 48 & 1 & 1,9 &,- 9 \\
52 & 1 & 1,9 &,- 9 \\
54 & 1 & 1,9 &,- 9 \\
56 & 2 & 1,9 &, 1 \\
59 & 2 & 1,9 &, 1 \\
60 & 2 & 1,9 &, 1 \\
61 & 4 & 1,9 & 2,1 \\
62 & 2 & 1,9 &, 1 \\
63 & 1 & 1,9 &,- 9 \\
64 & 2 & 1,9 &, 1 \\
65 & 1 & 1,9 &,- 9 \\
66 & 2 & 1,9 &, 1 \\
67 & 2 & 1,9 &, 1 \\
69 & 2 & 1,9 &, 1 \\
71 & 1 & 1,9 &,- 9 \\
72 & 6 & 1,9 & 4,1 \\
73 & 3 & 1,9 & 1,1 \\
74 & 3 & 1,9 & 1,1 \\
75 & 2 & 1,9 &, 1 \\
76 & 2 & 1,9 &, 1 \\
78 & 2 & 1,9 &, 1 \\
79 & 1 & 1,9 &,- 9 \\
80 & 1 & 1,9 &,- 9 \\
81 & 1 & 1,9 &,- 9 \\
84 & 1 & 1,9 &,- 9 \\
85 & 1 & 1,9 &,- 9 \\
86 & 1 & 1,9 &,- 9 \\
\hline & & & \\
\hline & & &
\end{tabular}

Tabel 3. Dukungan kepada Calon Pemimpin

\begin{tabular}{lccc}
\hline & $\begin{array}{c}\text { Observed } \\
\text { N }\end{array}$ & $\begin{array}{c}\text { Expected } \\
\text { N }\end{array}$ & Residual \\
\hline $\begin{array}{l}\text { Dukungan } \\
\text { kepada } \\
\text { calon }\end{array}$ & 17 & 25,0 & $-8,0$ \\
laki-laki & & & \\
$\begin{array}{l}\text { Dukungan } \\
\text { kepada } \\
\text { calon } \\
\text { perempuan }\end{array}$ & 33 & 25,0 & 8,0 \\
Total & & & \\
\hline
\end{tabular}

\subsection{Hasil Utama Penelitian}

Masalah penelitian pertama yang hendak dijawab pada penelitian ini adalah apakah ada pengaruh antara ideologi peran jender terhadap pemberian dukungan kepada calon pemimpin perempuan pada organisasi kemahasiswaan. Untuk menjawabnya digunakan metode statistik Dummy Regression 
karena terdiri dari skala interval dan nominal yang dikotomi.

Menurut Sugiyono (2007), pedoman untuk memberikan interpretasi koefisien korelasi sebagai berikut:

$$
\begin{array}{ll}
0,00-0,199 & =\text { sangat rendah } \\
0,20-0,399 & =\text { rendah } \\
0,40-0,599 & =\text { sedang } \\
0,60-0,799 & =\text { kuat } \\
0,80-1,000 & =\text { sangat kuat }
\end{array}
$$

Hasil analisis regresi disajikan pada Tabel 4.

Pengolahan statistik berdasarkan tabel di atas menunjukkan nilai $\mathrm{R}$ sebesar 0,286 yang menunjukkan bahwa terjadi hubungan yang rendah antara ideologi peran jender dengan pemberian dukungan kepada calon pemimpin perempuan.

Berdasarkan tabel di atas juga diperoleh angka $\mathrm{R}^{2}$ $(\mathrm{R}$ Square $)=0,082(8,2 \%)$. Hal ini menunjukkan bahwa persentase sumbangan pengaruh variabel independen (ideologi peren jender) terhadap variabel dependen (pemberian dukungan kepada calon pemimpin perempuan) hanya sebesar $8,2 \%$ dan selebihnya dipengaruhi oleh faktor lainnya. Angka tersebut menunjukkan nilai pengaruh yang kecil antara ideologi peran jender terhadap pemberian dukungan kepada calon pemimpin perempuan.
Kemudian pada Tabel 4 tersebut juga terlihat bahwa nilai Sig. F Change $=p=0,044$, two tailed, yang berarti bahwa nilai $\mathrm{p}<\alpha(0,044<0,05)$, maka Ho ditolak. Hasil statistik ini menunjukkan bahwa hipotesis penelitian diterima yang berarti ada pengaruh antara ideologi peran jender terhadap pemberian dukungan kepada calon pemimpin perempuan pada organisasi kemahasiswaan.

Masalah penelitian yang kedua adalah apakah ada perbedaan ideologi peran jender pemilih perempuan yang memilih calon pemimpim perempuan dan yang memilih calon pemimpin lakilaki. Rata-rata skor skala SRI pada pemilih perempuan yang memilih calon pemimpin perempuan adalah $70,36(\mathrm{SD}=9,256)$ dan rata-rata skor skala SRI pada pemilih perempuan yang memilih calon pemimpin laki-laki adalah 65,12 $(\mathrm{SD}=6,735)$.

Pertanyaan penelitian kedua ini dijawab dengan

\begin{tabular}{|c|c|c|c|c|c|c|c|c|c|}
\hline \multirow[b]{2}{*}{ Model } & \multirow[b]{2}{*}{$\mathbf{R}$} & \multirow{2}{*}{$\begin{array}{c}\mathbf{R} \\
\text { Square }\end{array}$} & \multirow{2}{*}{$\begin{array}{c}\text { Adjuste } \\
\text { d R } \\
\text { Square } \\
\end{array}$} & \multirow{2}{*}{$\begin{array}{c}\text { Std. } \\
\text { Error of } \\
\text { the } \\
\text { Estimate } \\
\end{array}$} & \multicolumn{5}{|c|}{ Change Statistics } \\
\hline & & & & & $\begin{array}{l}\text { R Square } \\
\text { Change }\end{array}$ & $\begin{array}{c}\mathrm{F} \\
\text { Change }\end{array}$ & df1 & $\mathrm{df} 2$ & $\begin{array}{c}\text { Sig. F } \\
\text { Change }\end{array}$ \\
\hline 1 &, $286(a)$ & ,082 & 063 & ,463 & 082 & 1 & ,286(a) & 082 & 063 \\
\hline
\end{tabular}
menggunakan uji statistik Independent Sample T Test. Pengolahan dengan metode statistik t-test ditunjukkan pada Tabel 6.

Tabel 4. Regression

Tabel 5. Group Statistics

\begin{tabular}{clcccc}
\hline & $\begin{array}{c}\text { Dukungan kpd } \\
\text { Calon Pemimpin }\end{array}$ & N & Mean & $\begin{array}{c}\text { Std. } \\
\text { Deviation }\end{array}$ & $\begin{array}{c}\text { Std. } \\
\text { Error } \\
\text { Mean }\end{array}$ \\
\hline Skor Skala SRI & $\begin{array}{l}\text { Dukungan kepada } \\
\text { calon laki-laki }\end{array}$ & 17 & 65,12 & 6,735 & 1,633 \\
& $\begin{array}{l}\text { Dukungan kepada } \\
\text { calon perempuan }\end{array}$ & 33 & 70,36 & 9,256 & 1,611 \\
\hline
\end{tabular}


Tabel 6. Independent Samples Test

\begin{tabular}{|c|c|c|c|c|}
\hline & & & \multicolumn{2}{|c|}{ Skor Skala SRI } \\
\hline & & & $\begin{array}{c}\text { Equal variances } \\
\text { assumed }\end{array}$ & $\begin{array}{l}\text { Equal variances } \\
\text { assumed }\end{array}$ \\
\hline \multirow{9}{*}{$\begin{array}{l}\text { Levene's Test for } \\
\text { Equality of } \\
\text { Variances } \\
\text { t-test for Equality } \\
\text { of Means }\end{array}$} & \multicolumn{2}{|l|}{$\mathrm{F}$} & 1,775 & 1,775 \\
\hline & \multicolumn{2}{|l|}{ Sig. } & , 189 & , 189 \\
\hline & \multicolumn{2}{|l|}{$\mathrm{T}$} & $-2,067$ & $-2,067$ \\
\hline & \multicolumn{2}{|l|}{ Df } & 48 & 48 \\
\hline & \multicolumn{2}{|l|}{ Sig. (2-tailed) } &, 044 &, 044 \\
\hline & \multicolumn{2}{|l|}{ Mean Difference } & $-5,246$ & $-5,246$ \\
\hline & \multicolumn{2}{|c|}{ Std. Error Difference } & 2,537 & 2,537 \\
\hline & \multirow{2}{*}{$\begin{array}{l}95 \% \text { Confidence } \\
\text { Interval of the } \\
\text { Difference }\end{array}$} & Lower & $-10,348$ & $-10,348$ \\
\hline & & Upper &,- 144 &,- 144 \\
\hline
\end{tabular}

Sebelum dilakukan Uji T Test, sebelumnya dilakukan uji kesamaan varian (homogenitas) dengan $\mathrm{F}$ test (Levene's Test), artinya jika varian sama maka Uji T menggunakan Equal Variance Assumed (diasumsikan varian sama) dan jika varian berbeda menggunakan Equal Variance Not Assumed (diasumsikan varian berbeda). Kriteria pengujian $\mathrm{F}$ Test berdasarkan probabilitas, menunjukkan nilai $\mathrm{p}$ value $(0,189>0,05)$, maka Ho diterima, artinya kedua varian sama (varian yang memilih pemimpin perempuan dan yang memilih pemimpin laki-laki adalah sama). Dengan ini penggunaan $\mathrm{t}$ menggunakan Equal Variance Assumed (diasumsikan varian sama).

Berdasarkan tabel 6 di atas, terlihat bahwa nilai $\mathrm{t}=-2,067$ (nilai min menunjukkan bahwa rata-rata skor SRI kelompok yang memberikan dukungan kepada pemimpin laki-laki lebih kecil dari mean skor SRI kelompok yang memberikan dukungan kepada pemimpin perempuan). Sedang nilai t tabel pada taraf signifikansi $5 \%$ untuk derajat kebebasan (df) $=48$ adalah 1,67. Berdasarkan perbandingan $\mathrm{t}$ hitung dan $\mathrm{t}$ tabel, dapat diambil keputusan bahwa -t hitung < -t tabel $(-2,067<-1,67)$, Ho ditolak. Kemudian berdasarkan probabilitasnya, terlihat pada tabel bahwa nilai Sig (2-tailed) $p=0,044$, yang berarti probabilitasnya dibawah 0,05: $\mathrm{p}<\alpha$ $(0,044<0,05)$, maka Ho ditolak.

Oleh karena nilai $-\mathrm{t}$ hitung < -t tabel $(-2,067<-$ $1,67)$, dan p value $(0,044<0,05)$, maka Ho ditolak. Dapat disimpulkan bahwa hipotesis penelitian diterima yang berarti ada perbedaan antara rata-rata skor SRI (ideologi peran jender) antara mahasiswi yang memilih calon pemimpin perempuan dengan rata-rata skor SRI mahasiswi yang memilih calon pemimpin laki-laki pada pemilihan calon pemimpin organisasi kemahasiswaan. Panda tabel Group Statistics terlihat rata-rata (mean) untuk skor SRI kelompok mahasiswi yang memberikan dukungan kepada calon pemimpin laki-laki adalah 65,12 yang lebih rendah dibandingkan dengan skor SRI mahasiswi yang memberikan dukungan kepada calon pemimpin perempuan.

\section{KESIMPULAN}

Berdasarkan uraian yang telah dilakukan, dapat dibuat kesimpulan sebagai berikut ini:

1) Terdapat pengaruh ideologi peran jender terhadap pemberian dukungan kepada calon pemimpin perempuan pada organisasi kemahasiswaan.

2) Ada perbedaan ideologi peran jender pemilih perempuan yang memilih calon pemimpin perempuan dan calon pemimpin laki-laki.

Merujuk kepada penelitian-penelitian sebelumnya di Amerika Serikat menyatakan bahwa calon legislator perempuan memiliki peluang lebih besar untuk dipilih oleh perempuan (King, dalam Ilmi 2004). Sejalan dengan hasil penelitian ini yang dilakukan pada mahasiswi Universitas Al Azhar Indonesia diperoleh hasil bahwa rata-rata mahasiswi mempunyai ideologi peran jender yang cenderung modern. Lebih lanjut diperoleh hasil bahwa terdapat perbedaan ideologi peran jender pemilih perempuan (mahasiswi) yang memilih calon pemimpin perempuan dengan yang memilih calon pemimpin laki-laki, dimana skor skala Sex Role Ideology (SRI) mahasiswi yang memilih pemimpin perempuan lebih tinggi dibanding skor SRI yang memilih pemimpin laki-laki. Hasil tersebut memperlihatkan bahwa ideologi peran 
jender memberikan pengaruh terhadap pemberian dukungan kepada calon pemimpin perempuan, yang mana pada penelitian ini dilihat melalui pemilihan pemimpin/ketua organisasi kemahasiswaan KMF. Meskipun secara statistik, ideologi peran jender tersebut hanya memberikan pengaruh $8,2 \%$ terhadap pemberian dukungan kepada calon pemimpin perempuan, dan selebihnya ditentukan oleh faktor lain.

Kemudian pada penelitian Ilmi Amalia, M. Psi pada tahun 2004 yang berjudul "Peranan Faktor Jender, Isu Politik, dan Identifikasi Partai Politik pada Pemilihan Calon Legislatif Perempuan" didapatkan hasil bahwa calon legislator perempuan dan calon legislator laki-laki memiliki peluang yang sama untuk dipilih oleh pemilih perempuan dan tidak ada perbedaan ideologi peran jender antara pemilih calon legislator perempuan dan lakilaki. Dalam survey lainnya, William dan Best (1990) mengistilahkan bahwa peran sosial yang telah ditetapkan oleh masyarakat sebagai ideologi peran jender. Dalam masyarakat terdapat dua kutub ideologi mengenai hubungan perempuan dan lakilaki, yaitu: (1) ideologi tradisional yang menyatakan adanya superioritas laki-laki terhadap perempuan dan adanya peran-peran yang berbeda antara laki-laki dan perempuan, dan (2) ideologi modern yang melihat tidak adanya perbedaan antara laki-laki dan perempuan serta menentang adanya penguasaan antara yang satu dan yang lainnya. Hasil survei menunjukkan bahwa sebagian besar responden menyatakan adanya perbedaan peran dan kemampuan antara perempuan dan lakilaki yang berarti sebagian besar respoden menganut ideologi peran jender tradisional.

Akan tetapi, survei itu dilakukan sebelum sosialisasi mengenai kesadaran jender marak dibicarakan. Saat ini, sosialisasi kesadaran jender sangat gencar dilakukan. Sehingga perbedaan hasil penelitian ini dengan survey di atas bisa saja disebabkan karena kondisi pengetahuan masyarakat saat ini termasuk mahasiswa, makin meningkat dikarenakan peran serta Lembaga Swadaya Masyarakat (LSM) dalam kajian-kajian yang fokus terhadap isu jender, serta pemberitaan di berbagai media baik cetak maupun elektronik. Responden pada penelitian ini juga cenderung mempunyai ideologi peran jender yang lebih modern, sehingga menyebabkan ideologi peran jender tersebut menjadi salah satu hal yang mempengaruhi dukungan yang diberikan pemilih perempuan kepada calon pemimpin perempuan karena mereka melihat tidak ada perbedaan antara laki-laki dan perempuan untuk menjadi pemimpin.

Hal lain yang bisa menyebabkan perbedaan tersebut adalah karena jumlah sampel pada penelitian ini lebih sedikit, sehingga hasil penelitian ini hanya bisa di generalisir pada lingkup yang lebih kecil pula.

Pada penelitian ini variabel ideologi peran jender dapat menjadi prediktor walaupun kecil. Penelitian selanjutnya dapat mempertimbangkan variabel lainnya, seperti pengaruh pemahaman nilai-nilai agama, pengaruh jender stereotipi, posisi ideologi pemilih, atau kepribadian kandidat.

Saran Metodologis:

1) Penelitian selanjutnya diharapkan dapat diperkuat dengan menambahkan metode pengumpulan data lainnya selain skala, seperti wawancara atau kuesioner yang mencantumkan pertanyaan terbuka (open question).

2) Penelitian ini menggunakan sampel dari kelompok mahasiswi dengan jumlah yang sedikit, sehingga sulit untuk digeneralisasi. Sebaiknya, untuk penelitian selanjutnya dapat dipergunakan sampel dengan karakteristik yang lebih beragam dengan jumlah yang lebih besar.

3) Penelitian selanjutnya dapat diperluas dengan penelitian pada pemilih laki-laki sehingga dapat memperkaya hasil penelitian.

Penelitian ini menunjukkan bahwa perempuan saat ini sudah mulai menganut ideologi peran jender yang lebih modern, dimana perempuan mempunyai kedudukan yang sama dengan laki-laki. Namun perlu kiranya pemahaman ini disertai dengan pemahaman agama, sehingga ideologi peran jender tersebut masih tetap memperhatikan batasanbatasan tertentu yang sudah dikodratkan oleh Allah SWT. Sebagaimana yang telah difirmankan Allah SWT dalam surat An Nisa' ayat: 34, yang artinya: "Laki-laki adalah pemimpin atas kaum perempuan".

\section{DAFTAR ACUAN / PUSTAKA}

[1] Amalia, Ilmi, "Peranan Faktor Jender, Isu Politik dan Identifikasi Partai Politik Pada Pemilihan Calon Legislatif Perempuan", Skripsi, Jakarta : F.Psikologi - UI, 2004

[2] Azwar, S., Sikap Manusia, Teori dan Pengukurannnya, Yogjakarta : Pustaka Pelajar, 2003 
[3] Bahsin, Kamla, Memahami Gender, Jkt : Teplok Press, 2002

[4] Cameron J.E \& Lalonde R.N, Social Identificaton and Gender Related Ideology in Women and Men, British Journal of Social Psychology, 2001.

[5] Guilford, J.P. \& Benyamin Fruchter, Fundamental Statistics in Psychology and Education, Tokyo: Kogakusha Mc Graw Hill Book Co, 1981.

[6] Hadi, Sutrisno, Statistik, Jilid I Cet III, Yogyakarta: Fakultas Psikologi UGM, 1987.

[7] Hair, J.F, Anderson, R.E, Tatham, R.L, \& Black, W.C, Multivariate Data Analysis, $5^{\text {th }}$ ed., New Jersey : Prentice Hall, 1998.

[8] Halida, Rizka \& Hamdi Muluk, "Hubungan Komponen-komponen Keterlibatan Psikologis Mahasiswa Dalam Politik Dengan Intensi mahasiswa Untuk Memberikan Suara Pada Pemilihan Umum Presiden", Jurnal Psikologi Sosial, Jakarta : F.Psi - UI, 2004.

[9] Kaplan, R.M \& Saccuzo, D.P, Psychological Testing Priciples Application, Issues, $3^{\text {rd }}$ ed., California : Broke/ Cole, 1993.

[10] Kerlinger, F.N \& Lee, H.B, Foundations of Behavioral Research, $4^{\text {th }}$ ed., California : Harcourt College Publisher, 2001.
[11] Kementerian Negara Pemberdayaan Perempuan, Kesetaraan dan Keadilan Gender bagi Organisasi Masyarakat Keagamaan, Jakarta : 2006.

[12] King, D.C., \& Matland, R. E, Gender and the Impact of Candidate Gender in Congressional Elections:Results of an Experiment, Makalah dipresentasikan pada pertemuan The Women Transforming Congress Conference, Oklahoma, 2000

[13] Nunnally, J.C \& Berstein, I.H, Psychometric Theory, $3^{\text {rd }}$ ed., New York : McGraw Hill, 1994.

[14] Priyatno, Duwi, Mandiri Belajar SPSS (Statistical Product and Service Solution), Jakarta: Media Kom, 2008.

[15] Robbins, Stephen, Perilaku Organisasi, terj., Jakarta : Prenhalindo, 1996.

[16] Sudjana, Metoda Statistika, Bandung: Tarsito, 1996.

[17] Sarwono, S.W, Pengantar Umum Psikologi, Jakarta : Rajawali Press, 2000.

[18] Sawono,S.W, Psikologi Sosial, Jakarta : Balai Pustaka, 2002.

[19] Toha, Miftah, Perilaku Organisasi, Jakarta : Rajawali Pers, 1996 